Assiut Scientific Nursing Journal

http://asnj.journals.ekb.eg

http://www.arabimpactfactor.com

\title{
Relationship Between Clinical Learning Environment and Students' Critical Thinking Skills
}

\author{
Eman Mohamed Ahamed ${ }^{1}$, Om Hashem Gomaa Ragab ${ }^{2}$, Sahara Fahmy Elsaied ${ }^{3}$ \& Ghada Hassan Ahmed ${ }^{4}$. \\ Lecturer of Nursing Administration, Faculty of Nursing, South Valley University, Egypt. \\ Lecturer of Nursing Administration, Faculty of Nursing, Sohag University, Egypt. \\ Assist Professor Obstetrics and Gynaecology, Faculty of Nursing, South Valley University, Egypt. \\ 4. Lecturer of Medical, Surgical Nursing, Faculty of nursing, Assiut University, Egypt.
}

\begin{abstract}
Students in learning environment learn how to apply knowledge, skills, communication and professionalization. So the objective of clinical learning is to improve students' professional critical thinking and decision-making skills and increase their self-confidence. Aim: the study aims to determine the Relationship between clinical learning environment and students' critical thinking skills. Research design: a correlational descriptive design used to conduct this study. Setting: the study conducted in faculty of nursing South Valley University. Subject: random sample from $2^{\text {nd }}, 3^{\text {rd }}$, and $4^{\text {th }}$ years' students to carry out the study total sample 384 students. Tools: three tools were used, $1^{\text {st }}$ : personal data and a question, does the clinical learning environment enhances your critical thinking skills? $2^{\text {nd. }}$ : Clinical Learning Environment Inventory and $3^{\text {rd }}$ : California Critical Thinking Skills Test. Results: the present study findings that there was satisfactory students' result $75 \%$ of clinical learning environment the mean and standard deviation $101.14 \pm 11.82$. Satisfactory $91.7 \%$ critical thinking skills the mean and standard deviation was 202.71 \pm 23.36 . Students' self-confidence was $100.0 \%$ unsatisfactory. Conclusion: There was satisfactory clinical learning environment in relation to satisfactory critical thinking skills and that in agreement with students' perception. Recommendations: faculty staff members at all departments should improve clinical learning environment to enhance critical thinking skills. Improve students' self-confidence through: close supervision, good communication and training programs.
\end{abstract}

\section{Keywords: Students, Clinical Learning Environment, Critical Thinking Skills \& Self-confidence.}

\section{Introduction}

Nursing education is strongly related to theoretical and clinical teaching. Nursing students' clinical experiences is an important element of the nursing profession, as well as clinical teaching which is cornerstone of the nursing education. In this learning environment, students learn how to apply nursing knowledge, nursing skills, patient communication and professionalization and prepare themselves for practice in future workplaces (Bigdeli, et al., 2015, Van Graan et al., 2016) The objective of clinical education is to improve students' professional critical thinking and decision-making skills and increase their self-confidence (D'Souza et al., 2015, Arkana et al., 2018).

Clinical learning, defined as learning focused on and usually directly involving patients and their families, is vital for putting knowledge and skills into action. Hence, finding and developing appropriate clinical practice venues for quality student learning experiences is indispensable for bridging this knowledge-practice gap (National League for Nursing [NLN], 2008, Benner et al., 2010, Mayumi, 2017). Clinical Learning Environment has been defined as the interactive network of forces within the clinical setting that impacts nursing students' learning maintain that these interconnected influences include everything surrounding the nursing student in the setting (Mayumi, 2017).

However, learning in clinical environments has several benefits, but at the same time, it can be challenging, unpredictable, stressful, and constantly changing (Baraz et al., 2015, Jamshidi et al., 2016). Nursing students' describe CLE as the most anxietyprovoking component of nursing education. Students' clinical experiences have been transformed from "learning by doing" to evidential oriented learning. However, not all the clinical settings are conducive to students' learning outcomes or contributing to their competencies' development (Papastavrou et al., 2016). Nurse educators must develop evidence-based strategies that prepare new graduates to function in a dynamic health care environment. Student satisfaction with their clinical learning has been identified as a particular outcome of interest (Lovecchio et al., 2015). A well-directed clinical education promotes students' critical thinking, clinical judgments, decision making, clinical skills, clinical knowledge, and attitudes (Bifftu et al., 2018). Instructors' behaviors, such as role modeling, facilitation, guidance, and prioritization, are integral to the promotion of student critical thinking (Mayumi, 2017). 
Critical thinking is an interpretation, analysis, evaluation, inference, presenting, arguments, reflection, and dispositions (Ordem, 2017) Critical thinking is a generally accepted tool that entails elements of thought implicit in all reasoning, encourages important dialogues with oneself, allowing one to reason well and to adopt reasonable positions (Wang \& Zheng, 2016) Critical thinking is an essential process for a safe, efficient and skillful nursing intervention (Scriven, \& Paul, 2013, Potter et al., 2019). Critical thinking is a skill which can be thought and developed (Karakoç, 2016, Wang \& Zheng, 2016).

Critical thinking includes six basic elements, focus, reason, inference, situation, clarity, and overview (Hapsari, 2016) General critical thinking processes are not specific to nursing it includes: scientific method, problem solving and decision making. Critical thinking skills that are specific to clinical health care environment include: clinical inferences, diagnostic reasoning and clinical problem solving skills. The specific critical thinking competency in nursing is the nursing process, which involves each of the specific critical thinking competencies (Potter et al., 2019) In this modern healthcare environment, with its complex technology and patient interventions, nurses require critical thinking skills. Lack of the critical thinking skills negatively affects the quality of service and the professionalism. The more effective the nurses are in critical thinking, the better their services become in increasing quality of life and protecting and improving public health. So it is highly important to provide students with an insight into critical thinking (Arli et al., 2017).

\section{Significance of the study}

Initial social interview with some students of Faculty of Nursing South Valley University during clinical work revealed that, the strong relation between clinical learning environment and critical thinking skills may be found. So that urges the researchers to study that relation.

\section{Aim of the study}

The aim of this study is to determine the Relationship between clinical learning environment and students' critical thinking skills.

\section{Subjects \& Methods \\ Research design}

A correlational descriptive design used to conduct this study.

\section{Setting}

The study has been conducted in faculty of nursing South Valley University.

\section{Subjects}

The subject was random sample from $2^{\text {nd }}, 3^{\text {rd }}$, and $4^{\text {th }}$ years' students to carry out the study who actually experienced clinical learning practice related to nursing subjects. The sample size calculated based on the total number of each group as the following: $2^{\text {nd }}$ year group (A) medical surgical nursing 59 students; $2^{\text {nd }}$ year group (B) critical care nursing 59 students; $3^{\text {rd }}$ year group $(\mathrm{A})$ pediatric nursing $69 ; 3^{\text {rd }}$ year group (B) maternity and gynaecology nursing $69 ; 4^{\text {th }}$ year group (A) nursing administration 64 ; and $4^{\text {th }}$ year group (B) community health nursing 64 . The total sample was 384. Epi Info program version 7.2.3.1, confidence level $80 \%$ and acceptable margin of error 5\% used to the calculate sample. Students practice clinical learning at Qena University Hospital, General Hospital and schools.

\section{Tools of data collection}

First Tool: developed by the researcher includes: personal data: sex, age and scientific department. An additional question was added, does the clinical learning environment enhances your critical thinking skills?

Second Tool: Clinical Learning Environment Inventory (CLEI) questionnaire adopted from Newton et al., (2010) The tool consisted of 40 positive and negative statements classified as: student-centeredness 13, affordances and engagement 11 , individualization 3 , fostering workplace learning 6 , valuing nurses' work 4 , innovative and adaptive culture 3 . Scoring based on 4 points Likert scale for positive statements started by strongly agree four to strongly disagree one while for negative statements the score was strongly agree one to strongly disagree four.

Third Tool: California Critical Thinking Skills Test (CCTST) questionnaire adopted from Karakoç, (2016) It consisted of 75 positive statements divided to: truth seeking 12, open mindedness 12 , analyticity 11 , systematicity 11 , self-confidence 9 , inquisitiveness 10 and cognitive maturity 10 . Scoring based on 4 points Likert scale started by strongly agree four to strongly disagree one.

The total score for each tool and sup item was summed students who have $60 \%$ and more considered having satisfactory results the reverse for those have less than $60 \%$.

\section{Methods}

Preparatory phase encompasses: literature review, a rabic translation of the study tools, pilot study, reliability, validity and official permissions. This phase started from November 2018 to the next phase.

Pilot study

conducted on 20 students randomly selected from different years Faculty of Nursing South Valley University students. Minor modifications was made so number of the pilot study had been excluded from the actual study sample. 


\section{Reliability}

was done using Cronbach's alpha test. Clinical Learning Environment Inventory reliability was 0.68 and California Critical Thinking Skills Test reliability was 0.84 .

Validity: to ensure content validity a jury of five professors in the field of nursing reviewed the tools.

Official permission was obtained from the dean of

Faculty of Nursing South Valley University.

Data collection phase:

Data collected throughout November 2019.

\section{Ethical considerations}

Research proposal approved from ethical committee,
Faculty of Nursing, Sohag University. Oral consent obtained from students who are willing to participate in the study. All consideration was given for confidentiality and anonymity.

\section{Statistical Design}

The collected data entered, verified for any errors and analyzed using (SPSS) version 20 for windows. The collected data tabulated and presented using frequencies and percentages, means and standard deviations and Chi-square test. Test of significance were considered as follow: insignificant $P \geq 0.05$; significant $\mathrm{P}<0.05$ and highly significant $\mathrm{P}<0.01$.

\section{Results}

Table (1): Personal characteristics of Students included in the study ( $n=384$ students).

\begin{tabular}{|l|l|l|}
\hline \multicolumn{1}{|c|}{ Personal characteristics } & N. & \% \\
\hline \hline Sex & & 20.6 \\
\hline$-\quad$ Male & 79 & $\mathbf{7 9 . 4}$ \\
\hline$-\quad$ Female & 305 & \\
\hline Age & & $\mathbf{2 0 . 6 5} \pm \mathbf{1 . 0 2 9}$ \\
\hline$-\quad$ Mean \pm Std. Deviation & \multicolumn{2}{c|}{} \\
\hline
\end{tabular}

Table (2): Mean score of clinical learning environment as reported by students in the present study $(\mathrm{n}=384$ students)

\begin{tabular}{|c|c|c|c|c|c|}
\hline \multirow[t]{2}{*}{ Clinical learning environment } & \multicolumn{2}{|c|}{$\begin{array}{c}\text { Unsatisfactory } \\
\text { results }\end{array}$} & \multicolumn{2}{|c|}{$\begin{array}{c}\text { Satisfactory } \\
\text { results }\end{array}$} & \multirow{2}{*}{$\begin{array}{l}\text { Mean } \pm \text { Std. } \\
\text { Deviation }\end{array}$} \\
\hline & n. & $\%$ & n. & $\%$ & \\
\hline Student-centeredness & 166 & 43.2 & 218 & 56.8 & $31.92 \pm 4.57$ \\
\hline Affordances and engagement & 56 & 14.6 & 328 & 85.4 & $28.77 \pm 3.68$ \\
\hline Individualization & 210 & 54.7 & 174 & 45.3 & $7.16 \pm 2.01$ \\
\hline Fostering workplace learning & 158 & 41.1 & 226 & 58.9 & $14.91 \pm 3.03$ \\
\hline Valuing nurses' work & 115 & 29.9 & 269 & 70.1 & $10.55 \pm 2.17$ \\
\hline Innovative and adaptive culture & 166 & 43.2 & 218 & 56.8 & $7.84 \pm 2.07$ \\
\hline Total & 96 & 25.0 & 288 & 75.0 & $101.14 \pm 11.82$ \\
\hline
\end{tabular}

Table (3): Mean score of critical thinking skills as reported by students in the present study $(\mathrm{n}=384$ students $)$

\begin{tabular}{|c|c|c|c|c|c|}
\hline \multirow[t]{2}{*}{ Critical thinking skills } & \multicolumn{2}{|c|}{$\begin{array}{c}\text { Unsatisfactory } \\
\text { results }\end{array}$} & \multicolumn{2}{|c|}{ Satisfactory results } & \multirow[t]{2}{*}{ Mean \pm Std. Deviation } \\
\hline & n. & $\%$ & n. & $\%$ & \\
\hline Truth seeking & 49 & 12.8 & 335 & 87.2 & $33.40 \pm 5.39$ \\
\hline Open mindedness & 60 & 15.6 & 324 & 84.4 & $31.44 \pm 5.23$ \\
\hline Analyticity & 76 & 19.8 & 308 & 80.2 & $29.47 \pm 4.60$ \\
\hline Systematicity & 76 & 19.8 & 308 & 80.2 & $28.66 \pm 4.36$ \\
\hline Self confidence & 384 & 100.0 & 0 & 0.0 & $25.58 \pm 3.86$ \\
\hline Inquisitiveness & 57 & 14.8 & 327 & 85.2 & $27.63 \pm 4.20$ \\
\hline Cognitive maturity & 106 & 27.6 & 278 & 72.4 & $26.53 \pm 4.03$ \\
\hline Total & 32 & 8.3 & 352 & 91.7 & $202.71 \pm 23.36$ \\
\hline
\end{tabular}


Table (4): Mean score of clinical learning environment in relation to critical thinking skills as reported by students in the present study $(n=384$ students $)$.

\begin{tabular}{|l|l|c|c|c|c|c|c|}
\hline \multirow{2}{*}{\multicolumn{2}{|c|}{ Items }} & \multicolumn{2}{|c|}{ Clinical learning environment } & \multirow{2}{*}{$\mathbf{X}^{\mathbf{2}}$} & \multirow{2}{*}{ P - Value } \\
\cline { 3 - 6 } & \multicolumn{2}{|c|}{ Unsatisfactory results } & \multicolumn{2}{|c|}{ Satisfactory results } & & \\
\cline { 3 - 6 } & $\mathbf{n .}$ & $\mathbf{\%}$ & $\mathbf{n .}$ & $\mathbf{\%}$ & \\
\hline $\begin{array}{l}\text { Critical } \\
\text { thinking } \\
\text { skills }\end{array}$ & $\begin{array}{l}\text { Unsatisfactory } \\
\text { results }\end{array}$ & 28 & 7.3 & 4 & 1.0 & \multirow{2}{*}{$\mathbf{7 2 . 7 3}$} & $\mathbf{0 . 0 0 0 * *}$ \\
\cline { 2 - 6 } & Satisfactory results & 68 & 17.7 & 284 & $\mathbf{7 4 . 0}$ & \\
\hline
\end{tabular}

** P. Value is highly significant at $P<0.01$

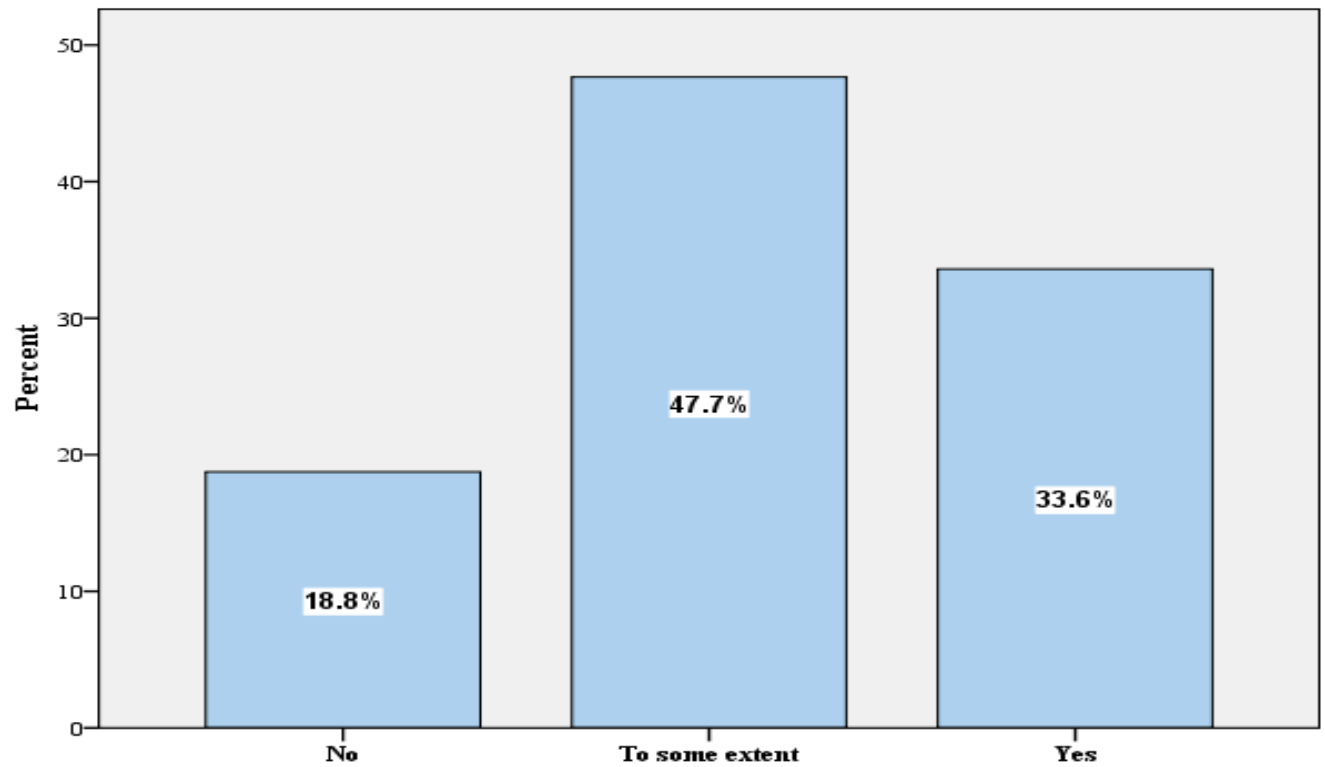

Does clinical learning environment enhances your critical thinking skills?

Fig. (1): Relation between clinical learning environment and critical thinking skills

Table (5): Relation between students perception that clinical learning environment enhances critical thinking skills in relation to department ( $\mathrm{n}=\mathbf{3 8 4}$ students).

\begin{tabular}{|c|c|c|c|c|c|c|c|c|}
\hline \multirow{3}{*}{ Department } & \multicolumn{6}{|c|}{$\begin{array}{l}\text { Students perception that clinical learning } \\
\text { environment enhances critical thinking skills }\end{array}$} & \multirow{3}{*}{$\mathbf{X}^{2}$} & \multirow{3}{*}{$P$ - value } \\
\hline & \multicolumn{2}{|c|}{ No } & \multicolumn{2}{|c|}{ To some extent } & \multicolumn{2}{|c|}{ Yes } & & \\
\hline & $\mathrm{n}$. & $\%$ & $\mathrm{n}$. & $\%$ & n. & $\%$ & & \\
\hline Medical surgical nursing & 2 & 2.8 & 37 & 20.2 & 20 & 15.5 & \multirow{6}{*}{60.99} & \multirow{6}{*}{$0.000 * *$} \\
\hline Critical and emergency nursing & 23 & 31.9 & 17 & 9.3 & 19 & 14.7 & & \\
\hline Pediatric Nursing & 21 & 29.2 & 34 & 18.6 & 14 & 10.9 & & \\
\hline $\begin{array}{l}\text { Maternity and gynecological } \\
\text { nursing }\end{array}$ & 3 & 4.2 & 43 & 23.5 & 23 & 17.8 & & \\
\hline Nursing administration & 13 & 18.1 & 33 & 18.0 & 18 & 14.0 & & \\
\hline Community health nursing & 10 & 13.9 & 19 & 10.4 & 35 & 27.1 & & \\
\hline
\end{tabular}

** P. Value is highly significant at $P<0.01$ 
Table (6): Relation between clinical learning environment and critical thinking skills in relation to department ( $n=384$ students).

\begin{tabular}{|c|c|c|c|c|c|c|c|c|}
\hline \multirow{3}{*}{ Department } & \multicolumn{2}{|c|}{$\begin{array}{c}\text { Clinical learning } \\
\text { environment }\end{array}$} & \multirow{3}{*}{$\mathbf{X}^{2}$} & \multirow{3}{*}{$\begin{array}{c}P \text { - } \\
\text { value }\end{array}$} & \multicolumn{2}{|c|}{ Critical thinking skills } & \multirow{3}{*}{$\mathbf{X}^{2}$} & \multirow{3}{*}{$P$ - value } \\
\hline & \begin{tabular}{|} 
Unsatisfacto \\
ry
\end{tabular} & Satisfactory & & & Unsatisfactory & Satisfactory & & \\
\hline & $\%$ & $\%$ & & & $\%$ & $\%$ & & \\
\hline $\begin{array}{l}\text { Medical } \\
\text { surgical } \\
\text { nursing }\end{array}$ & 3.9 & 11.5 & \multirow{6}{*}{6.69} & \multirow{6}{*}{0.245} & 0.3 & 15.1 & \multirow{6}{*}{14.12} & \multirow{6}{*}{$0.015^{*}$} \\
\hline $\begin{array}{l}\text { Critical and } \\
\text { emergency } \\
\text { nursing }\end{array}$ & 3.4 & 12.0 & & & 0.3 & 15.1 & & \\
\hline $\begin{array}{l}\text { Pediatric } \\
\text { Nursing }\end{array}$ & 6.0 & 12.0 & & & 2.6 & 15.4 & & \\
\hline $\begin{array}{l}\text { Maternity and } \\
\text { gynecological } \\
\text { nursing }\end{array}$ & 2.9 & 15.1 & & & 2.6 & 15.4 & & \\
\hline $\begin{array}{l}\text { Nursing } \\
\text { administration }\end{array}$ & 4.9 & 11.7 & & & 1.6 & 15.1 & & \\
\hline $\begin{array}{l}\text { Community } \\
\text { health nursing }\end{array}$ & 3.9 & 12.8 & & & 1.0 & 15.6 & & \\
\hline
\end{tabular}

$* P$. Value is significant at $P<0.05$

Table (1): Shows that, the highest percentage $79.4 \%$ of students were females. The Mean score of age was $20.65 \pm 1.29$.

Table (2): Shows that, the highest percentages $85.4 \%$ and $70.1 \%$ were for satisfactory students' results in regards to affordances and engagement and valuing nurses' work respectively. For total clinical learning environment satisfactory students' results percentage was $75 \%$. The mean and standard deviation was $101.14 \pm 11.82$.

Table (3): Clarifies that, all critical thinking skills sub items have satisfactory student results highest percentages except self-confidence sub item all student results percentage $100.0 \%$ was unsatisfactory. As regards to total critical thinking skills students' results percentage was $91.7 \%$ satisfactory. Mean score was $202.71 \pm 23.36$.

Table (4): Declares that, the highest percentage was $74.0 \%$ for satisfactory students' results according to clinical learning environment in relation to critical thinking skills. There was highly statistical significance difference $\mathrm{X}^{2}=72.73 \& \mathrm{P}<0.01$.

Figure (1): Illustrates that, the highest percentage was $47.7 \%$ students perceived that clinical learning environment enhances critical thinking skills to some extent, followed by $33.6 \%$ of students perceived that skills enhances.
Table (5): Shows that, the highest percentages were $31.9 \%$ for students' at critical and emergency nursing department who perceived that clinical learning environment not enhances critical thinking skills. $23.5 \%$ for students' at maternity and gynecological nursing department who perceived that skills enhances to some extent. $27.1 \%$ for students' at community health nursing department who perceived that skills enhances. There was highly statistical significance difference $\mathrm{X}^{2}=60.99 \& \mathrm{P}<0.01$

Table (6): Demonstrates that, there was statistical significance difference between students' unsatisfactory/satisfactory results according to critical thinking skills in relation to department $\mathrm{X}^{2}=$ $14.12 \& \mathrm{P}<0.05$.

\section{Discussion}

The clinical component of undergraduate clinical education is a critical area in nursing programs. The evaluation of the clinical learning environment is crucial to determine if the clinical experience provides essential learning opportunities as well as a supportive environment (Phillips, et al., 2017). Information and experiences provided in a clinical atmosphere play an essential role along with the theoretical information when providing critical thinking insight (Arli, et al., 2017). 
This study was conducted with the aim is to determine the impact of clinical learning environment on faculty of nursing students' critical thinking skills. The findings of the present study clarified that the highest percentage of the study sample was females aged 20 years old. That may because the nursing profession is more magnetic for females. This result supported by Shivers, et al., (2017) in their study the pre-registration nursing student's quality of practice learning founded that the highest proportion of respondents were females, aged 18-24 years old. In the same line Hakim (2014) studied nursing students' satisfaction about their field of study for students in the second, third and fourth years founded that Mean score of age.

The findings of the current study clarified that the highest percentages of the clinical learning environment was satisfactory for the students of faculty of nursing with an average mean score. That may because they feel more engaged and valuing nursing work. These result consisted by Shivers, et al., (2017) studied the nursing student's quality of practice learning they founded that students were moderately satisfied with their clinical learning experience. In the same line Hakim (2014) showed that nursing students had little satisfaction concerning clinical environment. The current results were contradicted with Bigdeli, et al., (2015) study of clinical learning environments revealed that nursing students' were not satisfied with clinical environment. Moreover the current study results contradicted with the qualitative research of Baraz et al., (2015) founded that Iran nursing students learning environment was unsupportive. In addition to Günay, \& Kılınç, (2018) showed that nursing students found their clinical knowledge and skills insufficient and usually failed to transfer their theoretical knowledge into clinical practices.

Current study revealed that although students' critical thinking skills results were satisfactory with average mean and standard deviation those students' selfconfidence was unsatisfactory. That may be related to the students as beginners in nursing field fear from low experience in clinical practice. This gives an evidence for academicians to provide more concentration on students' self-confidence. This finding was in accordance with Arli, et al., (2017) studied the critical thinking and caring in nursing students founded that the critical thinking disposition scale mean was average. The results of the current study contradicted with Mohamed \& Mohammed (2016) revealed that critical thinking disposition and its sub items for internship nursing students were neutral.

The study result reveals that the faculty of nursing students' results was satisfactory for clinical learning environment in relation to critical thinking skills. This may be due to clinical learning environment place the students in many different situations that urge the student's to be critical thinkers for confrontation of those situations facing them in clinical learning environment. That supported by students' perception of clinical learning environment enhances critical thinking skills. That may be due to the student awareness about them both critical thinking disposition and the clinical learning. That also supports the study hypothesis. That supports the study hypothesis.

This finding was supported by Kermansaravi, et al., (2013) they founded that critical thinking ability of senior nursing students was more than junior students and the ability of critical thinking in clinical nursing students had been lower than the seniors. Moreover Arli, et al., (2017) they revealed that clinical practices positively affect critical thinking with a significant decrease was found in the critical thinking scale average when the year of study decreased. The current study results contradicted with Mohamed, et al., (2017) showed that total mean score of critical thinking disposition for student nurses' postinternship experience was lower than pre-internship, with statistically significant difference that may be referred mainly to the transition internship program itself.

The current study declares that students' perceived that critical and emergency nursing clinical learning environment not enhances critical thinking skills; maternity and gynecological nursing enhances skills to some extent; while community health nursing enhances skills. The difference was highly statistically significance. That may related to students in community health nursing and in maternity and gynecological nursing communicate with healthy clients and practice in many different clinical areas, while those at critical and emergency nursing do not have that option. These result consisted by Shivers, et al., (2017) they founded that community placement of students had significantly higher scores than hospital placement. Lack of control of the environment may influence the quality of the student learning. Also learning environment can influence students' experiences. In the same line Cantero, et al., (2016) they stated that there are certain factors of the physical learning environment that influence behavior and social relations; these include environmental and spatial factors. Although Bjørk, et al., (2014) they founded that there was no great difference in students are learning environment during clinical placements in mental care, home care and nursing homes in relation to hospital settings. 


\section{Conclusion}

The study concluded that the highest percentage of the study sample was females aged 20 years old. The clinical learning environment was satisfactory for the students. Although students' critical thinking skills were satisfactory the students' self-confidence was unsatisfactory. The mean score was average for both clinical learning environment and critical thinking skills. There was satisfactory clinical learning environment in relation to critical thinking skills and that in agreement with students' perception. This study clarifies that, there was statistical significance difference between students' results of critical thinking skills in relation to department.

\section{Recommendations}

1. Encourage faculty staff members at all departments to enhance clinical learning environment as that affects students' critical thinking skills.

2. More support should be given to improve students' self-confidence through close supervision during practice, answer students' questions, improve communication between staff members and students, training programs for students concerning self-confidence.

3. Critical thinking should be included in nursing teaching policies as a curriculum.

\section{Reference}

1. Arkana, B., Ordinb, Y., \& Yılmaze, D., (2018): Undergraduate nursing students' experience related to their clinical learning environment and factors affecting to their clinical learning process. Nurse Education in Practice journal homepage: www.elsevier.com/locate/nepr

2. Arli, S., Bakan, A., Ozturk, S., Erisik, E., \& Yildirim, Z., (2017): Critical Thinking and Caring in Nursing Students. International Journal of Caring Sciences January- April 2017 Volume 10 | Issue 1| Page 471-478.

3. Baraz, S., Memarian, R., \& Vanaki Z., (2015): Learning challenges of nursing students in clinical environments: A qualitative study in Iran. Journal of Education and Health Promotion; 4: 52.

4. Benner, P., Sutphen, M., Leonard, V., Day, L., \& Shulman, S., (2010): Educating nurses: A call for radical transformation. San Francisco, CA: Jossey-Bass.

5. Bifftu, B., Dachew, B., Tiruneh, B., Ashenafie, T., Tegegne, E., \& Worku, W., (2018): Effective Clinical Teaching Behaviors Views of Nursing Students and Nurse Educators at University of Gondar, Northwest Ethiopia:

$\begin{array}{lccr}\text { Cross-Sectional } & \begin{array}{c}\text { Institution } \\ \text { Published }\end{array} & \text { Based } & \text { Study. } \\ \text { 1. doi: } 10.15171 / \text { jcs.2018.019. } & 2018 & \text { Sep } \\ & & \end{array}$

6. Bigdeli, S., Pakpour, V., Aalaa, M., Shekarabi, R., Sanjari, M., Haghani, H., \& Mehrdad, N., (2015): Clinical learning environments (actual and expected): perceptions of Iran University of Medical Sciences nursing students. Med J Islam Repub Iran. 2015; 29: 173. Published online 2015 Feb 4.

7. Bjørk, I., Berntsen, K., Brynildsen, G., \& Hestetun. M., (2014): Nursing students' perceptions of their clinical learning environment in placements outside traditional hospital settings. Journal of Clinical Nursing, 23, 2958-2967, doi: 10.1111/jocn.12532.

8. Cantero, J., Mira, R., \& López-ChaoV., (2016): Influence of Physical Learning Environment in Student'sBehavior and Social Relations. Anthropologist; 25(3): 249-253. D'Souza, S., Karkada, N., Parahoo, K., \& Venkatesaperumal, R., (2015): Perception of and satisfaction with the clinical learning environment among nursing students. Nurse Educ Today; 35: 833-840.

9. Günay, U., \& Kılınç, G., (2018): The transfer of theoretical knowledge to clinical practice by nursing students and the difficulties they experience: A qualitative study. Nurse Educ Today; 2018 Jun: 65:81-86.

10. Hakim, A., (2014): Nursing Students' Satisfaction about Their Field of Study. J Adv Med Educ Prof; 2(2): 82-87.

11. Hapsari, S., (2016): A Descriptive Atudy of the Critical Thinking Skills of Social Science Junior High School. Journal of Education and Learning. Vol.10 (3) pp. 228-234.

12. Jamshidi, N., Molazem, Z., Sharif, F., Torabizadeh, C., \& Kalyani, M., (2016): The Challenges of Nursing Students in the Clinical Learning Environment: A Qualitative Study. The Scientific World Journal; Vol. (2016), Article ID 1846178, P.p. 1-7.

13. Karakoç, M., (2016): The Significance of Critical Thinking Ability in terms of Education. International Journal of Humanities and Social Science, Vol. 6, No. 7; 81-84.

14. Kermansaravi, F., Navidian, A., \& Kaykhaei, A., (2013): Critical Thinking Dispositions among Junior, Senior and Graduate Nursing Students in Iran. Procedia - Social and Behavioral Sciences, 83(0), 574-579.

15. Lovecchio. C., DiMattio, M., \& Hudacek, S., (2015): predictors of undergraduate Nursing student satisfaction with Clinical Learning 
environment: A secondary Analysis. july/august 2015. doi: 10.5480/13-1266.

16. Mayumi, N., (2017): Creating an Optimal Clinical Learning Environment for Undergraduate Nursing Students: Preceptors' Views. (2017).Scholar Archive. 3910. http://digitalcommons.ohsu.edu/etd/3910.

17. Mohamed, A., \& Mohammed, S., (2016): Relationship between critical thinking disposition of nursing Students and their performance for patients on haemodialysis. IOSR Journal of Nursing and Health Science; Vol. (5), No. (6), P.p. 45-53. DOI: 10.9790/1959-0506064553.

18. Mohamed, M., Elsayed, S., Mohamed, T., \& Abdelrazek, F., (2017): Internship and Clinical Decision Making combined with Critical Thinking Disposition among Nursing Students. The 3rd International Scientific Conference "Innovations and Evidence Based Practices in Nursing", held at 20th April 2017, by Faculty of Nursing, Port Said University, Egypt.

19. National League for Nursing, (2008): preparing the next generation of nurses to practice in a technology-rich environment: An informatics agenda. New York, NY: Author. Retrieved on May 10, 2012 from www.nln.org/aboutnln/PositionStatements/index .htm.

20. Newton, M., Jolly, C., Ockerby, M., \& Cross, M., (2010): Clinical Learning Environment Inventory: factor analysis. Journal of Advanced Nursing 66(6), 1371-1381. doi: 10.1111/j.13652648.2010.05303.x

21. Ordem, E., (2017): Developing CriticalThinking Dispositions in a Listening/Speaking Class. English Language Teaching; Vol. 10, No. $1 ; 2017$

22. Papastavrou, E., Dimitriadou, M., Tsangari, H., \& Andreou, C., (2016): Nursing students' satisfaction of the clinical learning environment: a research study. Bio Med Central Nursing, 15:44. doi: 10.1186/s12912-016-0164-4

23. Phillips, K., Mathew, L., Aktan, N., \& Catano, B., (2017): Clinical education and student satisfaction: An integrative literature review. International Journal of Nursing Sciences 4 (2017) 205-213.

24. Potter, P., Perry, A., Stockert, P., \& Hall, A., (2019): Essentials for Nursing Practice. $9^{\text {th }}$ ed. Chapter 8: critical thinking. Elsevier, Canada. Pp. 100-116.

25. Scriven, M., \& Paul, R., (2013): Defining critical thinking. Retrieved February 23 2013, from //www.criticalthinking.org/University/univclass/Defining.Html
26. Shivers, E., Hasson, F., \& Slater, P., (2017): Pre-registration nursing student's quality of practice learning: Clinical learning environment inventory (actual) questionnaire. Nurse Education Today; 55: 58-64.

27. Van Graan, A., Williams, M., \& Koen, M., (2016): Professional nurses' understanding of clinical judgment: A contextual inquiry. HEALTH SA GESONDHEID; 21: 280-293.

28. Wang, X., \& Zheng, H., (2016): Reasoning Critical Thinking: Is It Born or Made? Theory and Practice in Language Studies, Vol. (6), No. (6), Pp. 1323-1331. 